\title{
HOW MUCH “TECHNICS" IS THERE IN ELEMENTARY TECHNICAL EDUCATION?
}

\author{
[ILE ,TECHNIKI” JEST W EDUKACJI TECHNICZNEJ W \\ NAUCZANIU POCZĄTKOWYM?]
}

\author{
Marcin Musiol
}

\section{doi: 10.18355/PG.2017.6.1.15}

\begin{abstract}
Contemporary man is on all sides surrounded by technical creations. Devoid of them, he would probably survive not too long. Therefore, in order to use them rationally and harmlessly, a man should be properly qualified and have a suitably high level of technical culture. These shall be acquired within technical education executed on different levels of schooling. This obvious argument is however crushing into educational reality. The long-standing treatment of technical education as a "garbage can" of educational content and focusing on manual works during technical education classes, has led to a situation, that technical education is now perceived from the aspect of "making of a birdfeeder". In the opinions of not just parents alone, but also the teachers, it holds a status of a course of little significance. This is to some extent also visible in frequently amended core curricula. If we add lack of technical laboratories adjusted to children of primary school age and low technical competencies of primary education teachers, the condition of technical education in grades 1-3 is not reflected in positive colours.
\end{abstract}

\section{Key words}

technics, technical education, primary education, core curriculum content.

\begin{abstract}
Abstrakt
Współczesny człowiek otoczony jest zewsząd wytworami techniki. Ich pozbawiony prawdopodobnie nie przeżyłby zbyt długo. Zatem, by racjonalnie i bezpiecznie z nich korzystać powinien posiadać odpowiednie kompetencje i odpowiednio wysoki poziom kultury technicznej. Osiągnąć je powinien w ramach edukacji technicznej realizowanej na różnych etapach kształcenia. Ten oczywisty argument zderza się jednakże z rzeczywistością edukacyjną. Wieloletnie traktowanie edukacji technicznej jako „śmietnika” treści kształcenia oraz koncentrowanie się w trakcie jej zajęć na pracach wytwórczych doprowadziło do sytuacji postrzegania jej w perspektywie „wykonywania karmnika”. W opiniach nie tylko rodziców, ale także nauczycieli ma ona status przedmiotu mało istotnego. To w pewnej mierze widoczne jest także w często zmienianych podstawach programowych. Gdy do tego dodać brak pracowni technicznych przystosowanych do potrzeb dzieci w wieku wczesnoszkolnym oraz niski poziom kompetencji technicznych nauczycieli edukacji wczesnoszkolnej, to sytuacja edukacji technicznej w klasach 1-3 nie prezentuje się w pozytywnych barwach.
\end{abstract}

\section{Słowa kluczowe}

technika, edukacja techniczna, nauczanie początkowe, treści programowe. 


\section{Wprowadzenie}

Człowiek XXI wieku żyje, pracuje i odpoczywa w budynkach wykonanych z wysoko przetworzonych materiałów, mediów potrzebnych do życia dostarczają mu elektrownie, ciepłownie i wodociągi, ubiera się $\mathrm{w}$ odzież $\mathrm{z}$ różnych materiałów, korzysta z różnych środków transportu, narzędzi ICT itp. Nawet surwiwal, czyli próby przeżycia $\mathrm{w}$ ekstremalnych warunkach podejmowane są $\mathrm{z}$ użyciem nowoczesnych technologii: odzieży termoaktywnej i membranowej, narzędzi ze stali nierdzewnej wysokiej jakości, ostrzonych laserowo itp. Zaawansowanie technologiczne wytworów techniki stale wzrasta, powstają nowe materiały, a urządzenia techniczne coraz częściej sterowane są elektronicznie. Za tymi zmianami powinien nadążać współczesny człowiek. Jest to na tyle istotne, że kompetencje techniczne znalazły się wśród tzw. kompetencji kluczowych, w grupie kompetencji matematycznych i podstawowych kompetencji naukowo-technicznych, którymi są zdolność do wykorzystywania i posługiwania się narzędziami i urządzeniami technicznymi...(Zalecenia Parlamentu: 17). Do elementów kompetencji należą: wiedza, umiejętności, postawy i nawyki (Huk, 2008: 26). Wysoki poziom kompetencji technicznych jest wyznacznikiem kultury technicznej danego społeczeństwa.

Współczesny młody człowiek powinien osiągnąć odpowiedni poziomu kompetencji technicznych w ramach edukacji technicznej realizowanej na różnych etapach edukacji ogólnokształcącej. Edukacja ta realizowana jest w przedszkolu praktycznie w marginalnym zakresie. Dlatego ciężar wdrażania dziecka w świat techniki spoczywa de facto na edukacji szkolnej, a wszystko zaczyna się na jej pierwszym etapie - nauczaniu początkowym.

Edukacja techniczna wiązana jest współcześnie ściśle z procesem wychowania. Waldemar Furmanek (2007: 174) pisze o wychowaniu przez technikę, którego sens dla szkoty ogólnoksztatcacej sprowadza się do wprowadzania wychowanka w świat wartości jakie niesie ze sobą wspótczesna technika.

W rzeczywistości edukacyjnej występują jednak trudności, które sprawiają, że nie są wykorzystywane potencjalne możliwości optymalnej realizacji treści edukacji technicznej. Niektóre z tych trudności zostały opisane w tym opracowaniu.

\section{Edukacja techniczna w ujęciu podstaw programowych}

Pytanie, będące tytułem opracowania, wbrew pozorom nie ma wzbudzić u czytelnika natychmiastowego zainteresowania, a zostało zadane $\mathrm{z}$ troską o zbyt łatwe marginalizowanie potrzeby realizacji edukacji technicznej, a tym samym marnotrawienie możliwości optymalnego kształtowania kompetencji technicznych uczniów klas początkowych.

Z wymienionych elementów kompetencji kluczowych wszystkie są kształtowane w procesie edukacji technicznej. Jednakże faktycznej ewaluacji efektów kształcenia podlegają wiedza teoretyczna i umiejętności techniczne. Te dwa elementy stanowią zatem trzon w zapisach podstaw programowych i będą poddawane analizom.

W podstawie programowej z 1999 roku (Rozporządzenie Ministra Edukacji Narodowej z dnia 15 lutego 1999 r.) dla edukacji wczesnoszkolnej treści kształcenia ujęte zostały w całkowitej integracji, czyli bez ich dzielenia na poszczególne rodzaje edukacji. W ówczesnych założeniach edukacji technicznej można je jednak z jej zapisów wyłuskać. Były to: żywność i żywienie, bezpieczeństwo, w tym poruszanie się po drogach publicznych, rozpoznawanie sygnałów alarmowych o niebezpieczeństwie, poznawanie pracy w wybranych zawodach, urządzenia techniczne powszechnego użytku (bezpieczne użytkowanie), wykorzystanie materiałów (papier, drewno, tkanina, metal, tworzywa sztuczne, materiały przyrodnicze) w działalności manualnej oraz organizacja pracy (planowanie, organizacja stanowiska, racjonalne wykorzystanie materiału i czasu). W treściach tych 
nie skonkretyzowano obszarów wiedzy teoretycznej i umiejętności praktycznych. Takie zapisy podstawy programowej dawały wiele swobody autorom programów nauczania i samym nauczycielom.

Znaczne zmiany wprowadzono w podstawie programowej obowiązującej od września 2009 roku (Rozporządzenie Ministra Edukacji Narodowej z dnia 23 grudnia 2008 r.). W podstawie tej dokonano oddzielnych zapisów dla klasy pierwszej i wspólnych dla klas drugiej i trzeciej. Edukacja techniczna (użyto dla niej nazwy zajęcia techniczne) dla klasy pierwszej składała się $\mathrm{z}$ dwóch działów programowych: wychowania technicznego oraz dbałości o bezpieczeństwo własne i innych. W zakresie wiedzy teoretycznej uczniowie klasy pierwszej powinni wiedzieć, jak ludzie wykorzystywali dawniej oraz dziś wodę i wiatr, znać zasady działania urządzeń takich, jak: latarka, odkurzacz, zegar; znać zagrożenia wynikające z niewłaściwego używania narzędzi i urządzeń technicznych; wiedzieć jak bezpiecznie poruszać się na drogach, zachowywać w środkach komunikacji i zachować się w sytuacji wypadku. Natomiast umiejętnościami pierwszoklasistów miały być: czynności związane z wykonaniem np. latawca, wiatraczka, tratwy, wagi, szałasu, namiotu, toru przeszkód, konstruowanie urządzeń technicznych $\mathrm{z}$ gotowych zestawów oraz posługiwanie się latarką, odkurzaczem, zegarem. Działami programowymi dla klas drugiej i trzeciej były: środowisko techniczne, proces powstawania wytworów techniki oraz bezpieczeństwo własne i innych. Wiedza teoretyczna dla tych klas dotyczyła: sposobów wytwarzania przedmiotów codziennego użytku, organizowania działania technicznego oraz bezpiecznego poruszania się po drogach, korzystania ze środków komunikacji a także zachowania się w sytuacji wypadku. Znacznie bogatsze były umiejętności, nie tylko manualne, ale także umysłowe. Były to: rozpoznawanie maszyn i urządzeń transportowych, wytwórczych, informatycznych, budowli, określanie wartości urządzeń technicznych, planowanie kolejnych czynności w działaniach technicznych, dobieranie materiałów i narzędzi do wykonania wytworów technicznych, odmierzanie potrzebnej ilości materiałów, cięcia papieru i tektury, montaż modeli z papieru i tworzyw sztucznych na podstawie instrukcji, fakultatywnie montaż obwodów elektrycznych, właściwe używanie narzędzi i urządzeń technicznych.

W podstawie programowej z 2012 roku (Rozporządzenie Ministra Edukacji Narodowej z dnia 27 sierpnia 2012 r.) nie wprowadzono zmian w edukacji technicznej dla nauczania początkowego.

Znacznych, a do tego nielogicznych i niezrozumiałych zmian dotyczących edukacji technicznej dokonano natomiast w podstawie programowej z 2014 roku. Pominięto w niej bowiem wszystkie treści realizowane w klasie pierwszej (zapisane w podstawie programowej z 2008 roku). Marcin Musioł (2016, s. 82) wymienił kilka potencjalnych powodów tej zmiany. Najbardziej prawdopodobnym $\mathrm{z}$ nich było wdrażanie rządowego projektu zwanego „darmowym podręcznikiem” i niezgodność treści tego podręcznika dla klasy pierwszej z zapisami podstawy programowej z 2008 roku. Wskazanie tego powodu, jako najbardziej prawdopodobnego, wynika ze zbieżności terminów wdrażania podręcznika i wprowadzenia zmian programowych.

Zmiany pojawią się także w podstawie programowej mającej obowiązywać od roku szkolnego 2017/2018 (Projekt podstawy programowej z 01.12.2016 r.). Zajęcia techniczne zostały w tym Projekcie nazwane edukacją techniczną. Wyróżniono w nim trzy działy programowe: organizacja pracy (1), informacja techniczna, materiały i technologie wytwarzania (2) oraz stosowanie narzędzi i obsługa urządzeń technicznych (3). W działach tych umiejętności wyraźnie przeważają nad wiedzą teoretyczną. Wiedza ta dotyczy: zachowania ładu, porządku i dobrej organizacji miejsca pracy ze względów bezpieczeństwa oraz działania i funkcji narzędzi, urządzeń wykorzystywanych w gospodarstwie domowym i w szkole. Natomiast umiejętności mają być kształtowane m.in. w zakresie: planowania i realizacji własnych projektów, oceniania projektów i prac zgodnie z poznanymi wartościami, 
organizowania pracy własnej z wykorzystaniem urządzeń technicznych i technologii, odczytywania podstawowych informacji technicznych i stosowania w działaniu materiałów, narzędzi i urządzeń zgodnie z instrukcją, korzystania z podstawowych narzędzi pomiarowych, składania, zgniatania, przerywania, przecinania po linii prostej, przecinania po łamanej, po okręgu, wycinania otworów, nakłuwania, zwijania, przeplatania, zawiązywania, oklejania, szycia ściegiem przed igłą, krojenia chleba lub innych produktów spożywczych, smarowania, wykonywania przedmiotów użytkowych, montowania wybranych modeli urządzeń technicznych, np. lampionu, latawca, papierowej zakładki, torby, dekoracji świątecznej z użyciem światła elektrycznego, wykonywania przedmiotów użytkowych, w tym dekoracyjnych $\mathrm{z}$ zastosowaniem połączeń nierozłącznych: sklejania klejem, wiązania, szycia lub zszywania zszywkami, sklejania taśmą itp. oraz używając połączeń rozłącznych: spinania spinaczami biurowymi, wiązania sznurkiem, wstążką ozdobną, wykorzystania taśm, zszywek, wykonywania z instrukcją przedmiotów użytkowych i prostych modeli technicznych, w tym multimedialnych oraz posługiwania się prostymi narzędziami pomiarowymi, urządzeniami z gospodarstwa domowego, a także urządzeniami dostępnymi w szkole, zgodnie $\mathrm{z}$ zasadami bezpiecznego użytkowania. Niestety, jak można zauważyć, w propozycji tej powrócono do idei realizowania technologii żywienia w ramach edukacji technicznej.

Jeżeli projekt ten zostanie przyjęty $\mathrm{w}$ nowej podstawie programowej $\mathrm{w}$ tej lub nieznacznie zmienionej formie, to jej zapisy pozwolą na realizację wielu prac technicznych realizowanych w latach obowiązywania poprzednich podstaw programowych, a więc rzetelnie przygotowanych już przez nauczycieli.

W każdej $\mathrm{z}$ zaprezentowanych podstaw programowych w obszarze edukacji technicznej zawarte są treści mające bezpośrednie odniesienie do techniki. Są jednakże i takie, które $\mathrm{z}$ techniką mają niewiele wspólnego. Przykładami są wychowanie komunikacyjne czy też wspomniana już technologia żywienia.

W edukacji wczesnoszkolnej istotne są integrowanie oraz korelowanie treści różnych rodzajów edukacji, np. technicznej z przyrodniczą. Alina Budniak (2009) oraz Dorota Klus-Stańska (1999) zaprezentowały wiele środków potrzebnych do realizacji doświadczeń, które mogą być wykonane przez uczniów w ramach zajęć technicznych. Dyskutować można nad sensownością przyswajania przez uczniów w wieku wczesnoszkolnym danej wiedzy teoretycznych lub też kształtowania u nich tych, a nie innych umiejętności technicznych, postaw czy nawyków. Niemniej prawie każda podstawa programowa (najmniej podstawa z 2014 roku) dawała możliwość kształtowania u uczniów elementarnych kompetencji technicznych.

Niestety, możliwości te nie są w pełni wykorzystywane, a głównymi trudnościami w optymalnym realizowaniu edukacji technicznej są:

\section{Trudność 1}

Zbyt częste zmiany programowe w edukacji wczesnoszkolnej. Cykl powtarzalności zajęć tej edukacji wynosi trzy lata. Gdy dany temat opracowywany jest przez nauczyciela po raz pierwszy mogą pojawić się w jego realizacji niedoskonałości, a nawet poważne błędy (niedoszacowanie lub przeszacowanie dotychczasowej wiedzy uczniów lub ich możliwości działania, dobranie niewłaściwych przykładów lub ćwiczeń, a także czynności, które mają być wykonane przez uczniów itp.). Wspomniany cykl sprawia, że zajęcia te, w poprawionej formule, będą realizowane za trzy lata. Po ich drugiej realizacji nadal mogą być udoskonalane - częste zmiany w podstawach programowych nie dają jednakże nauczycielom szansy takiego doskonalenia $\mathrm{i}$ to dla wielu tematów. Jedynie niektóre $\mathrm{z}$ nich mogą zostać „przemycone" do materiału kształcenia realizowanego według zmienionej podstawy programowej. 


\section{Trudność 2}

Niskie poziomy kompetencji technicznych nauczycieli i kandydatów na nauczycieli nauczania początkowego, poziomu myślenia technicznego i twórczego myślenia technicznego, brak podejmowania przez nich działań technicznych doskonalących sprawności, niechęć lub strach przed wykonywaniem prac wytwórczych narzędziami lub materiałami niebezpiecznymi itp. Zarówno kandydaci do zawodu, jak i nauczyciele edukacji wczesnoszkolnej określają siebie zazwyczaj mianem humanistów, traktując przedmioty ścisłe i techniczne jak zło konieczne.

Często na lekcjach prowadzonych przez studentów lub nauczycieli można zaobserwować pewne nieprawidłowości czy trudności w: wykorzystaniu rysunku elementu, który mają wykonać uczniowie, wytłumaczeniu poszczególnych operacji, które mają wykonać uczniowie, precyzyjnym wytłumaczeniu uczniom, jakie materiały (ich rodzaj, właściwości, ilość, gabaryty) i narzędzia będą im potrzebne na zajęciach, posługiwaniu się pojęciami technicznymi, wykorzystaniu mediów dydaktycznych oraz ewaluacji wiedzy i działań technicznych uczniów, nie tylko w określeniu kryteriów oceniania, ale także w przeniesieniu tych kryteriów na ocenę opisową (Musioł, 2009: 276).

Tej sytuacji nie zmieni przygotowanie zawodowe nauczycieli. Na studiach muszą oni zostać przygotowani do realizowania ośmiu rodzajów edukacji wczesnoszkolnej oraz wychowania przedszkolnego. Stąd zajęcia z zakresu edukacji technicznej są znacznie ograniczone (czasowo), a często także organizowane w zwykłej sali, zamiast w pracowni technicznej. Pewne możliwości w łagodzeniu skutków tej sytuacji występują w różnych formach doskonalenia zawodowego nauczycieli.

\section{Trudność 3}

W przypadku zajęć związanych z wykonywaniem prac wytwórczych w szkołach brak pracowni technicznych dostosowanych do potrzeb i możliwości uczniów w wieku wczesnoszkolnym. W polskiej rzeczywistości oświatowej wiele szkół nie posiada odpowiednio wyposażonej pracowni technicznej dla uczniów klas 4-6. Pracownie takie przeznaczone wyłącznie dla uczniów klas 1-3 są prawdziwą rzadkością. Brak pracowni technicznej sprawia, że uczniowie wykonują prace wytwórcze wykorzystując przygotowane przez rodziców lub zakupione półfabrykaty, a to właśnie ich wykonanie stanowi sedno działalności technicznej przy wykonaniu danego wytworu. W skrajnych przypadkach uczniowie ozdabiają wytwór, zatem zamiast pracy technicznej wykonują pracę plastyczną. Warto w tym miejscu wskazać na niekorzystne dla edukacji technicznej łączenie jej $\mathrm{z}$ edukacją plastyczną $\mathrm{i}$ stosowanie nazwy edukacja plastyczno-techniczna, zamiast integrowania i korelowania ich treści. Nazwy tej używają np. nauczyciele w ocenach opisowych, realizowane są zajęcia o tej nazwie na studiach pedagogicznych na kierunkach edukacja wczesnoszkolna, stosowana jest ona w tekstach naukowych. Podstawową wadą takiego podejścia jest zacieranie się granicy między tymi obszarami edukacjami i wystąpienie możliwości dominacji jednej z edukacji nad drugą - praktyka wskazuje, że najczęściej dominującą staje się edukacja plastyczna, uważana przez nauczycieli jako łatwiejsza, nie wymagająca pracowni, narzędzi czy urządzeń.

Realizacja zadań wytwórczych przez dzieci w wieku wczesnoszkolnym w pracowniach przeznaczonych dla uczniów klas 4-6 jest niezgodna z wymogami ergonomii. Stoły robocze są $\mathrm{w}$ nich za wysokie, narzędzia niedostosowane do wielkości ich dłoni, a często także zbyt ciężkie dla ich układu kostno-mięśniowego. Jednym z rozwiązań tego problemu jest przygotowanie jednej pracowni dla klas 1-3 i 4-6 (a wkrótce być może dla klas 4-8 - ta informacja będzie możliwa do sprecyzowania, gdy zatwierdzony zostanie ramowy plan nauczania dla zreformowanej ośmioletniej szkoły podstawowej, który zawierać będzie informacje o klasach, w których edukacja techniczna będzie realizowana). Stoły w takich pracowniach 
powinny posiadać regulację wysokości blatów roboczych, a narzędzia posegregowane dla uczniów w zależności od ich wieku i rozwoju fizycznego.

Innym rozwiązaniem problemu braku pracowni technicznej dla uczniów klas początkowych jest wyposażenie szkoły w „mobilną pracownię techniczną". Pracownię taką można wykonać na bazie metalowej szafki z szufladami na kółkach. Wyposażeniem takiej szafki mogą być: imadła przykręcane do stołu, podkładki chroniące stoły, piłki do drewna, pilniki, papier ścierny, ręczna lub elektryczna wiertarka, pistolet do klejenia na gorąco, kleje, cięgna, szydła, itp.

\section{Trudność 4}

Brak możliwości integrowania lub korelowania edukacji technicznej zwłaszcza z wiedzą z zakresu fizyki, np. wytłumaczenie uczniom na czym polega działanie latarki (podstawa programowa z 2009 r.) jest znacznie utrudnione, gdy uczniowie nie mają elementarnej wiedzy o prądzie elektrycznym i jego właściwościach.

\section{Konkluzje}

Rozważania nad edukacją techniczną nie powinny dotyczyć potrzeby jej realizacji, a tego, co i jak powinno być w jej ramach realizowane.

Głównym warunkiem skutecznej edukacji technicznej dzieci w młodszym wieku szkolnym jest integracja teoretycznego i praktycznego poznania elementarnych rzeczy, czynności i zjawisk związanych z techniką. Spełnienie tego warunku jest z kolei uzależnione od stopnia posiadanej przez dzieci świadomości roli, jaką technika spełnia w życiu człowieka (Drejer, 2010, s. 92). Nie mniej ważne jest także posiadanie tej świadomości przez nauczycieli realizujących tę edukację.

To właśnie działania i postawy nauczycieli są najbardziej znaczącym argumentem w odpowiedzi na pytanie zawarte w tytule tego opracowania. Niestety, posiadają oni często zbyt niski poziom kompetencji technicznych i myślenia technicznego, w tym twórczego, nie rozumieją istoty technicznych działań, co sprawia, że boją się powierzyć uczniom wykonywanie czynności stricte technicznych.

Znaczącym problemem w realizowaniu technicznych zadań wytwórczych jest także brak szkolnych pracowni technicznych ergonomicznie przystosowanych do możliwości fizycznych uczniów w wieku wczesnoszkolnym. Rozwiązaniem tego problemu mogłyby być mobilne pracownie techniczne.

W realizacji edukacji technicznej w klasach wczesnoszkolnych przeszkodą nie są zapisy tej czy innej podstawy programowej. Nauczyciel może przecież dokonać wyboru programu nauczania bogatego w treści tej edukacji, a w procesie jej realizacji sam może te treści dodatkowo wzbogacać. Trudnością w tej realizacji są jednakże zbyt częste zmiany zapisów w podstawach programowych, które nie sprzyjają doskonaleniu zajęć (ze względu na ich powtarzalność w trzyletnich okresach).

Realizację edukacji technicznej utrudnia także brak możliwości integrowania lub korelowania jej treści zwłaszcza z wiedzą z zakresu fizyki.

\section{Bibliographic references}

BUDNIAK, A. 2009. Doświadczenia przyrodnicze w poznawaniu środowiska przez uczniów klas początkowych: poradnik metodyczny, Katowice: „Deni-Press” Usługi Wydawnicze i Reklamowe. ISBN 978-83-907427-4-8.

DREJER, F. 2010. Wychowanie do techniki dzieci w młodszym wieku szkolnym, Jelenia Góra: Kolegium Karkonoskie. ISBN 978-83-926801-9-2.

FURMANEK, W. 2007. Jutro edukacji technicznej, Rzeszów: Wydawnictwo Uniwersytetu Rzeszowskiego. ISBN 978-83-7338-263-3.

HUK, T. 2008. Komputer w procesie kształtowania umiejętności kluczowych, Warszawa: „Difin”. ISBN 978-83-7251-925-2.

KLUS-STAŃSKA, D. 1999. W nauczaniu początkowym inaczej, Kraków; Oficyna Wydawnicza „Impuls”. ISBN 83-88030-06-X. 
LEEK, J. 2015. Ewolucja podstaw programowych kształcenia ogólnego w Polsce. Ku zmianie edukacyjnej. In KAMIŃSKA, M. (ed.) Wybrane problemy nauczania i wychowania. Z doświadczeń okresu transformacji, Płock: Oficyna Wydawnicza Szkoły Wyższej im. Pawła Włodkowica NOVUM. ISBN 978-83-62709-98-4. (http://dspace.uni.lodz.pl:8080/xmlui/bitstream/handle/11089/16885/Podstawy\%20pr ogramowe $\% 20 \mathrm{w} \% 20$ Polsce $\% 201999 \% 202009$. pdf? sequence=1\&isAllowed=y)

MUSIOŁ, M. 2011. Edukacja techniczna w klasach 1-3. Koncepcja analitycznometodyczna do realizowania w zintegrowanym programie, Katowice: AMgraf w Gliwicach. ISBN 978-83-929881-1-3.

MUSIOŁ, M. 2009. Wybrane problemy edukacji (ogólno) technicznej w nauczaniu początkowym, In VARGOVA, M. - HAZYOVA, M. (ed.), Aktuálne otázky a trendy v predprimarnom a primarnom vzdelavani, Ruzomberk. ISBN 978-80-8084-469-1.

MUSIOE, M. 2016, IT, Technical and Media Education in Grades 1-3 in the Package of Free Textbooks - a step towards the modernity or a sign of backwardness?, In KOSOVA B., MUSIOŁ, M. (ed.) School, curriculum and teacher in the second decade of the $21^{\text {st }}$ century. Polish-Slovak Confrontations, Torun: Wydawnictwo Adam Marszałek, 2016. ISBN 978-83-8019-564-6.

$\begin{array}{llllll}\text { PROJEKT PODSTAWY PROGRAMOWEJ } & \mathrm{z} & 01.12 .2016 & \mathrm{r} \text {. }\end{array}$ (https://men.gov.pl/projekt-podstawa-programowa)

ROZPORZĄDZENIE MINISTRA EDUKACJI NARODOWEJ z dnia 15 lutego 1999 r. w sprawie podstawy programowej kształcenia ogolnego. (Dz.U. $1999 \mathrm{nr} 14$ poz. 129).

(http://isap.sejm.gov.pl/DetailsServlet?id=WDU19990140129).

ROZPORZĄDZENIE MINISTRA EDUKACJI NARODOWEJ z dnia 23 grudnia

2008 r. w sprawie podstawy programowej wychowania przedszkolnego oraz kształcenia ogólnego w poszczególnych typach szkół. (Dz.U. 1999 nr 4 poz. 17). (isap.sejm.gov.pl/Download?id=WDU20090040017\&type=2)

ROZPORZĄDZENIE MINISTRA EDUKACJI NARODOWEJ z dnia 27 sierpnia 2012 r. w sprawie podstawy programowej wychowania przedszkolnego oraz kształcenia ogólnego w poszczególnych typach szkół (Dz. U. z 2012 r. poz. 977). (https://men.gov.pl/zycie-szkoly/ksztalcenie-ogolne/podstawa-

programowa/rozporzadzenie-o-podstawie-programowej-w-calosci.html).

ROZPORZĄDZENIE MINISTRA EDUKACJI NARODOWEJ z 30 maja 2014 r. zmieniające rozporządzenie $\mathrm{w}$ sprawie podstawy programowej wychowania przedszkolnego oraz kształcenia ogólnego w poszczególnych typach szkół (Dz. U. poz. $\quad 803$ ). (https://men.gov.pl/zycie-szkoly/ksztalcenie-ogolne/podstawaprogramowa/rozporzadzenie-ministra-edukacji-narodowej-zmieniajace-

rozporzadzenie-w-sprawie-podstawy-programowej-wychowania-przedszkolnegooraz-ksztalcenia-ogolnego-w-poszczegolnych-typach-szkol.html).

ZALECENIA PARLAMENTU EUROPEJSKIEGO I RADY w sprawie kluczowych kompetencji w uczeniu się przez całe życie, Bruksela 2005.

dr Marcin Musioł

Faculty of education and psychology

Slaski University, Katowice

Poland

marcin.musiol@us.edu.pl 